\title{
Opinion and Perception of Treasury Single Account Implementation: Implications for Revenue Generation and Utilisation in Nigeria
}

\author{
Abiola Abosede Solanke \\ Department of Accountancy, the Federal Polytechnic, Bida, Nigeria
}

Doi: 10.19044/esj.2018.v14n1p164 URL:http://dx.doi.org/10.19044/esj.2018.v14n1p164

\begin{abstract}
This study investigated opinion and perception of Treasury Single Account (TSA) adoption in Nigeria. This was with the view to highlighting TSA implications for revenue generation and utilisation in the country. Data were collected through the administration of structured questionnaire. The study analysed a total sample size of 200 purposively selected among Federal, State, Local Government and Private Sector Employees. The selection was purposive because the subject of investigation required education and awareness of its adoption in Nigeria. The outcome variable was perception dichotomised into positive and negative perception. Data were analysed using frequency and percentages, as well as analytic weighted mean. Result showed variation in acceptability attitude towards TSA implementation in Nigeria; $23.4 \%$ of respondents reported negative perception (non acceptability); and $76.6 \%$ of respondents reported positive perception (acceptability). The main factor that accounted for positive perception was the need to block all avenues of revenue leakages in the country, while the main factor that accounted for negative perception was the unavailability of funds to meets citizens' welfare needs. The study concluded that there are needs to improve public awareness of the benefits of TSA implementation in the country. Such awareness may optimize revenue generation and utilisation in Nigeria.
\end{abstract}

Keywords: Perception, TSA, opinion, effects, Nigeria

\section{Introduction}

The survival and growth of domestic and international economic systems relies fundamentally on effective financial management, which is the efficient and effective management of funds in such a manner as to achieve particular objective. Federal government agencies and Departments are required to have an effective financial management system as condition for receiving federal funds in Nigeria. Effective management requires that these 
government agencies must be able to account for and give accurate, current and full disclosure of their financial position. The adoption of TSA in Nigeria seeks to boost effective financial management of government agencies and departments. In other countries, where the Treasury Single Account policy has long been institutionalised, effective financial management is also the key goal of its adoption as done in Nigeria (Lienert, 2009).

Treasury Single Account (TSA) now being implemented in Nigeria, is a single bank account through which the government transacts all of its receipt and payments and gets a consolidated view of its cash position at any point in time for proper accountability; it is a unified structure of government bank accounts enabling consolidation and optimal utilisation of government cash resources (Eme \& Chukwurah, 2015). In other words, TSA is a network of subsidiary accounts all linked to a main account such that, transactions are effected in the subsidiary accounts but closing balances on these subsidiary accounts are transferred to the main account, at the end of each business day. It is a public accounting system under which all government revenue, receipt and income are collected into one single account usually maintained by the country's Central Bank and all payments due through the account as well (Adeolu, 2015).

The main reasons for TSA implementation in Nigeria is to maximize the use of cash resources through concentration and reduction in float costs, this is consistent with government policy to ensure prudence in the management of financial resources. With the TSA, government expects to block all loopholes and leakages of financial resources of the government and also ensure a robust financial management system (Taiwo, 2016; Isa, 2016). As observed by Ocheni (2016), the Federal Ministry of Finance in Nigeria lacks a unified view and centralised control over government cash resources. Consequently, cash lies idle for extended periods in numerous bank accounts held by spending agencies while government continues to borrow to execute its budget. It is based on these reasons that the current global revolution in government accounting becomes paramount following which Nigeria has initiated and implemented the TSA to assist in the better management of her economy.

The federal government believe that with TSA, national treasury can be delink from management over cash control at a transaction level. It is argued that TSA is the mechanism that provides for proper monitoring of government receipts and expenditure. In the Nigerian case, the TSA is expected to block most if not all the leakages that have been the bane of the growth of the economy. Olanipekun, Brimah and Owoleni (2015) stressed that the TSA is a financial programme for conducting the internal and external cash flows necessary for executing the public budget of the country, and it realises the premium utilisation of available liquidation. However, following the 
implementation of TSA in the country, opinions and perception about its merit or demerit varies significantly across the country and among professionals in the country. On one hand are positive opinions and perception, while negative opinions and perception have been expressed on the other hand. In the current study, positive opinion refers to acceptability of TSA while negative opinion refers to non-acceptability of TSA implementation in Nigeria.

A number of studies have examined the positive effects of TSA implementation in Nigeria. Isa (2016) observed that Government will borrow less and therefore, the debt servicing cost should reduce drastically to less than half of the current level. He further stressed that lot of funds previously unaccounted for will be uncovered. He chronicled the dividends of TSA to include: minimising transaction costs during budget execution; controlling the delay in the remittance of government revenues by collecting banks in both tax and non-tax revenues; making rapid payments of government expenses; facilitating reconciliation between banking and accounting data; efficient control and monitoring of funds allocated to various government agencies; and facilitating better coordination with the monetary policy implementation. Other benefits of the TSA are allowing complete and timely information on government cash resources; improving appropriation control; improving operational control during budget execution; enabling efficient cash management; reducing bank fees and transaction costs; facilitating efficient payment mechanisms; improving bank reconciliation and quality of fiscal data; and lowering liquidity reserve needs.

According to Oguntodu, Alalade, Adekunle and Adegbie (2016), the establishment of TSA is a key element of an efficient and effective public financial management system and an essential tool for minimising government borrowing costs. This opinion provided support for an earlier assertion by Onyekpere (2015), who asserted that the consolidation into a TSA paves way for the timely capture and payment of all due revenues into government coffers without the intermediation of multiple banking arrangements. This prevents revenue leakages in terms of revenue loss and mismanagement by operators of all revenue-generating agencies. With this comes better cash management practices since the Treasury can at all times have an overall view of government's cash position compared with the fragmented positions of different Ministries, Departments and Agencies (MDAs), which needs to be pooled together to get the overall picture of government revenue and expenditure.

Kolapo (2015) was of the opinion that the implementation of the TSA policy is good and meant to checkmate and block all the leakages that had bedeviled revenues that go into the Federation Account as required by laws of the federation. Likewise, Ngozi (2015) explained that the introduction of TSA had helped to reduce how government account was being overdrawn. She 
argued that several MDAs had hooked on to the TSA platform with substantial reduction in government's overdrawn financial position. Also, Kanu and Oyims (2015), were of the view that implementation of the TSA was a welcome scheme that could help reduce the mismanagement of public funds by revenue-generating agencies, like inflation, excess liquidity, and high interest rates of the government deposits. The use of multiple bank accounts allows misappropriation of huge sums of money belonging to all levels of government in the country. It encouraged corruption in the management of public finances, with the result that all tiers of governments became heavily cash-strapped. Philip (2015) also stressed that it was a step in the right direction to plug all financial leakages. He further explained that multiple accounts by government agencies made it possible for the MDAs to conceal some accounts for ulterior motives; hence, implementation of TSA will go a long way to checkmate corruption in the country.

In spite of the benefits of the TSA implementation in Nigeria as highlighted by previous studies, a number of studies have also provided information about the adverse effects of TSA in Nigeria. As observed by Kanu (2016), TSA may cause cash crunch and liquidity challenges to the banking sector, who before the introduction of the TSA feed fat on the 'float' created by the duplicated and unaccounted MDA's accounts in all the Commercial Banks in Nigeria. Also Augustin (2015) opined with the operation of TSA, federal universities find it extremely difficult to discharge their core responsibilities of teaching, research and community services, as well as engaging in international academic networking due to inadequate access to budgeted funds. Likewise, Obi (2016) revealed that the blanket implementation of the TSA policy by all federal government-owned institutions is crippling the efforts of the institutions to deliver on their set objectives, stressing that labour unions had no objection to the government's effort in ensuring accountability and transparency in the management of nation's resources through the TSA policy, he however noted that the Academic Staff Union of Universities (ASUU) was certain that the policy would rob the universities of the opportunity for short, medium and long-time planning particularly in relation to research development. In his assessment of the TSA, Charls (2016) argued that the policy had not only frustrated the functioning of academic and research institutions, but also eroded their autonomy. Mustapha (2016) also noted that government must be educated on the workings of the university system as it is impossible for administrators to run their relevant universities through the platform of TSA, adding that its implementation has adversely affected endowments, scholarships and management of research grants.

Clement (2015) opines that TSA implementation may reduce the bank's net liquidity position, credit may be constrained, and profitability of 
the bank may be adversely affected. The policy will further increase the frontiers of social crimes and violent criminal activities since the idle mind is the devil's workshop. Lending rates may become high because of scarcity of funds from which to lend to small, medium scale and large scale entrepreneurs in Nigeria which may stifle the manufacturing and productive sectors. This opinion was supported by Utsu,Mohamed and Obukeni (2016). They made it clear that the tertiary institutions have different designated accounts that might not be the best pulling it all into one account at once. As it stands, activities in most of our higher institutions may be grounded, and this might lead to a serious distortion of the regular academic calendar that has taken much effort to be stabilised in the country for some time now.

Other authors have also pointed out some of the adverse effects of TSA. For instance, Yusuf, Abdullahi, Emmanuel, and Emmanuel (2015) stated that deposit money banks stand to lose immensely from the implementation of TSA. This may arouse from the fact that public sector funds constitute a large chunk of commercial banks deposit. Indeed, it was estimated that commercial banks hold about N2.2 trillion public sector funds at the beginning of second quarter of 2015. Likewise, Udo and Esara (2016) argued that TSA may negatively impact the Nigerian Stock Exchange as deposit rates may reduce returns from equities to the money market. Consequently, inflation may increase; returns on real estate investments may fall; the manufacturing sector may also be affected negatively; unemployment may increase, and the banking sector may be worst hit by the TSA scheme in the short-term.

\section{Statement of the Research Problem}

Perception differs on the effects of TSA among individual organizations or governments in the country. Previous studies have either highlighted positive or negative effects of the TSA in Nigeria (Clement, 2015; Kolapo, 2015; Isa, 2016; Oguntodun et al. 2016; Clementina, 2016; Obi, 2016). However, studies have rarely assessed perception of TSA through population- based study. This study addresses the limitation by examining opinion and perception of TSA in a cross sectional study.

\section{Materials and Methods}

The study utilised primary data. A structured questionnaire was design for the study. The study adopted purposive sampling technique because the subject being investigated requires not only moderate level of education, but also moderate understanding of government revenue and expenditure. Data was collected from Federal, State, Local, and Private sector workers. In each sector, fifty (50) questionnaires were administered which resulted in the sample size of 200. However, only responses from 188 completed and returned questionnaires were analysed in the study. The outcome variable was 
perception which was dichotomised into positive and negative perception. Positive perception in the study is weighted scores that are 2.5 and above while negative perception is weighted scores that are less than 2.5. Data were analyzed using frequency and percentages as well as analytic weighted mean scores.

Statistical Tables

Table 1: Distribution of Respondents by Background Characteristics

\begin{tabular}{|c|c|c|}
\hline Respondents' Characteristics' & $\begin{array}{c}\text { Frequency } \\
(n=188)\end{array}$ & $\begin{array}{c}\text { Percentage } \\
(100)\end{array}$ \\
\hline \multicolumn{3}{|l|}{ Employer } \\
\hline Federal government & 46 & 24.47 \\
\hline State government & 73 & 38.83 \\
\hline Local government & 23 & 12.23 \\
\hline Private sector & 46 & 24.47 \\
\hline \multicolumn{3}{|l|}{ Media exposure } \\
\hline None & 91 & 48.40 \\
\hline Once in a week & 46 & 72.87 \\
\hline More than twice in a week & 51 & 100.00 \\
\hline \multicolumn{3}{|l|}{ Listening to radio } \\
\hline None & 104 & 55.32 \\
\hline Once & 22 & 11.70 \\
\hline More than twice & 62 & 32.98 \\
\hline \multicolumn{3}{|l|}{ Watching television per week } \\
\hline None & 85 & 45.21 \\
\hline Once & 22 & 11.70 \\
\hline More than twice & 81 & 43.09 \\
\hline \multicolumn{3}{|l|}{ Education } \\
\hline Primary & 09 & 4.79 \\
\hline Secondary & 69 & 36.70 \\
\hline Higher & 110 & 58.51 \\
\hline \multicolumn{3}{|l|}{ Occupation } \\
\hline Professional/managerial & 68 & 36.2 \\
\hline Skilled/technical & 105 & 55.9 \\
\hline Unskilled/clerical & 15 & 8.0 \\
\hline \multicolumn{3}{|l|}{ Work status } \\
\hline Senior staff & 82 & 43.62 \\
\hline Technical staff & 69 & 36.70 \\
\hline Junior staff & 37 & 19.68 \\
\hline
\end{tabular}


Table 2: Distribution of Respondents' View on Treasury Single Account

\begin{tabular}{|c|c|c|c|c|c|c|}
\hline $\begin{array}{l}\text { Views on treasury single } \\
\text { account }\end{array}$ & $\begin{array}{l}\text { SA } \\
\text { Freq } \\
(\%)\end{array}$ & $\begin{array}{l}\text { A } \\
\text { Freq } \\
(\%)\end{array}$ & $\begin{array}{l}\mathrm{N} \\
\text { Freq } \\
(\%)\end{array}$ & $\begin{array}{l}\mathrm{D} \\
\text { Freq } \\
(\%)\end{array}$ & $\begin{array}{l}\text { SD } \\
\text { Freq } \\
(\%)\end{array}$ & $\begin{array}{l}\mathrm{AW} \\
\text { mean }\end{array}$ \\
\hline $\begin{array}{l}\text { TSA allows complete and } \\
\text { timely information on } \\
\text { government cash }\end{array}$ & 1 & 2 & 25 & 43 & 117 & 2.34 \\
\hline $\begin{array}{c}\text { TSA improves operational } \\
\text { control during budget execution }\end{array}$ & 1 & 4 & 27 & 63 & 93 & 2.49 \\
\hline $\begin{array}{c}\text { TSA enables efficient cash } \\
\text { management }\end{array}$ & 1 & 5 & 34 & 50 & 98 & 2.42 \\
\hline $\begin{array}{l}\text { TSA reduces banks fees and } \\
\text { transaction cost }\end{array}$ & 5 & 16 & 31 & 58 & 78 & 2.77 \\
\hline $\begin{array}{c}\text { TSA improves bank } \\
\text { reconciliation and quality of } \\
\text { fiscal control } \\
\end{array}$ & 2 & 6 & 39 & 79 & 62 & 2.64 \\
\hline $\begin{array}{c}\text { TSA lower liquidity reserve } \\
\text { needs }\end{array}$ & 2 & 11 & 46 & 66 & 63 & 2,64 \\
\hline $\begin{array}{c}\text { TSA helps consolidate } \\
\text { government cash balances }\end{array}$ & 3 & 4 & 28 & 73 & 80 & 2.61 \\
\hline $\begin{array}{c}\text { TSA gives ministry of } \\
\text { finance/treasury oversight of all } \\
\text { government cash flow }\end{array}$ & 2 & 4 & 32 & 63 & 87 & 2.52 \\
\hline $\begin{array}{l}\text { TSA reduces the government } \\
\text { debt servicing cost }\end{array}$ & 7 & 13 & 29 & 56 & & 2.77 \\
\hline $\begin{array}{l}\text { TSA helps minimize the return } \\
\text { on investment of surplus cash }\end{array}$ & 5 & 6 & 30 & 77 & 70 & 2.72 \\
\hline $\begin{array}{l}\text { TSA helps reduces fraud } \\
\text {,corruption and financial } \\
\text { irregularities }\end{array}$ & 6 & 11 & 27 & 50 & 94 & 2.69 \\
\hline $\begin{array}{l}\text { TSA facilitate efficient payment } \\
\text { and mechanism }\end{array}$ & 1 & 14 & 32 & 7 & 69 & 3.33 \\
\hline $\begin{array}{l}\text { TSA result in mass } \\
\text { retrenchment of bank workers }\end{array}$ & 9 & 22 & & & 4 & 3.21 \\
\hline $\begin{array}{c}\text { TSA increase youth } \\
\text { unemployment }\end{array}$ & 10 & 31 & 36 & 59 & 52 & 3.15 \\
\hline $\begin{array}{c}\text { TSA increase interest rate for } \\
\text { borrowing }\end{array}$ & 13 & 35 & 47 & 52 & 41 & 3.19 \\
\hline $\begin{array}{l}\text { TSA can cripple the operation } \\
\text { of the agencies of government }\end{array}$ & 12 & 34 & 40 & 57 & 45 & 3.11 \\
\hline $\begin{array}{l}\text { TSA create inadequate capacity } \\
\text { in the form of access and ability } \\
\text { to use the internet to transaction }\end{array}$ & 12 & 27 & 45 & 52 & 52 & 3.08 \\
\hline $\begin{array}{l}\text { TSA increase poor economic } \\
\text { sustainability of credit to the } \\
\text { economy }\end{array}$ & 15 & 33 & 39 & 46 & 55 & 3.02 \\
\hline $\begin{array}{c}\text { TSA affects liquidity in the } \\
\text { banking system }\end{array}$ & 10 & 20 & 39 & 50 & 69 & 3.12 \\
\hline $\begin{array}{l}\text { TSA increase non availability of } \\
\text { credit to the economy }\end{array}$ & 13 & 23 & 41 & 53 & 58 & 3.11 \\
\hline $\begin{array}{l}\text { TSA enhance accountability of } \\
\text { government revenue, } \\
\text { transparency and avoid } \\
\text { misappropriation of government } \\
\text { funds }\end{array}$ & 5 & 9 & 29 & 53 & 92 & 2.64 \\
\hline
\end{tabular}




\begin{tabular}{|c|c|c|c|c|c|c|}
\hline $\begin{array}{c}\text { TSA ensure proper cash } \\
\text { management by eliminating idle } \\
\text { funds usually left with different } \\
\text { commercial banks }\end{array}$ & 1 & 3 & 38 & 63 & 83 & 2.46 \\
\hline $\begin{array}{c}\text { TSA improves prompt payment } \\
\text { in civil servant salaries }\end{array}$ & 6 & 10 & 44 & 62 & 66 & 3.23 \\
\hline $\begin{array}{c}\text { TSA reduces financial } \\
\text { corruption in the society }\end{array}$ & 9 & 6 & 41 & 59 & 73 & 2.74 \\
\hline $\begin{array}{c}\text { TSA affects banks profitability } \\
\text { TSA block all leakages that are } \\
\text { stumbling block to growth of } \\
\text { the economy }\end{array}$ & 7 & 9 & 33 & 61 & 78 & 2.74 \\
\hline $\begin{array}{c}\text { TSA allows CBN and ministry } \\
\text { of finance monitor cash inflows } \\
\text { and outflows }\end{array}$ & 3 & 5 & 33 & 63 & 84 & 2.57 \\
\hline $\begin{array}{c}\text { TSA leads to better fiscal and } \\
\text { monetary policy coordination }\end{array}$ & 6 & 6 & 38 & 70 & 68 & 2.71 \\
\hline $\begin{array}{c}\text { TSA paves way for timely } \\
\text { capture and payment of all } \\
\text { revenue into government coffers }\end{array}$ & 2 & 8 & 36 & 64 & 78 & 2.59 \\
\hline $\begin{array}{c}\text { TSA is a critical steps towards } \\
\text { boosting the economy and curb } \\
\text { corruption in the public finance }\end{array}$ & 5 & 8 & 31 & 55 & 89 & 3.23 \\
\hline
\end{tabular}

Note: AW=Analytical Weighted mean

Table 3: Perception of the respondents about TSA

\begin{tabular}{ccc}
\hline Perception & Frequency & Percent \\
\hline Negative & 44 & 23.4 \\
Positive & 144 & 76.6 \\
Total & 188 & 100.0 \\
\hline
\end{tabular}

\section{Results}

Table 1 presents the background characteristics of the respondents. Results showed that slightly a quarter of the respondents $(24.47 \%)$ were federal government workers, more than one-third (38.83\%) were state government workers, while slightly more than one-tenth of the respondents (12.23\%) were local government workers. Also, nearly a quarter of respondents $(24.47 \%)$ were private sector workers. Also, slightly more than half of respondents $(51.6 \%)$ read newspaper weekly, about $44.68 \%$ listened to radio weekly, while more than half of respondents $(54.79 \%)$ watched television at least once in a week. More than half of the respondents had attained higher education while more than one third of respondents had attained secondary education. In addition, $43.62 \%$ of the respondents were senior staff, $36.70 \%$ were technical staff, while $19.68 \%$ were junior staff.

Table 2 presents the analysis on perception of TSA in Nigeria. Perception was assessed by 30 constructs (statements), thereafter the positive and adverse effects of TSA were identified and scaled. Given that, all the questions have being measured according to a 5 point Linkert-scale. 
Analytical weighted mean was employed. Analytic weights are weights that are inversely proportional to the variance of an observation. Typically, the observations represent averages and the weights are the number of elements that gave rise to the average. In the analysis, weighted mean equals 2.5 was considered as the cutoff point this however indicated that if the mean value of a statement or construct is greater than 2.5, respondents had positive perception towards this statement, in other words, (agreed) while if the mean value of a statement is less than 2.5 respondents had negative perception towards this statement (disagreed). Mean score close to 5 indicate strongly agreed while mean score close to 1 indicate strongly disagreed. As presented in table 2, respondents disagreed with 4 statements while agreed with 26 statements. This suggests that respondents had positive perception about the adverse effects of the TSA. Table 3 summarized the general perception of the respondents. Respondents' perception was derived from re-categorizing 30 constructs with respect to analytic weighted means. These categories are negative and positive perception as presented in table 3 . The results showed that $23.4 \%$ that is close to one quarter of the respondents had negative perception about TSA while $76.6 \%$ of the respondents had positive perception.

\section{Discussion}

This paper investigated perception of positive and adverse effect of TSA implementation in Nigeria. Findings showed that $23.4 \%$ of the respondents had negative perception while $76.6 \%$ had positive perception about TSA. This showed that majority of the respondents accepted TSA implementation as a means of curbing leakages in government revenue in Nigeria. The result established that likely positive perception of TSA implementation in the general population of Nigeria. This provided support for the positive opinion of a number of researchers and public sector analyst in the country (Onyekpere, 2015; Clement, 2015; Isa, 2016; Oguntodu et.al, 2016), and contradicted negative opinions expressed by a number of researchers and analysts (Charls, 2016; Obi, 2016; Kanu, 2016). It is not expected that any government policy in the country whether already being implemented or still being developed, will exert the same opinion or perception from all sections of Nigeria particularly from the elite. It is however expected that policies that enhance general quality of life should be developed and implemented in the country.

It is against this backdrop that the TSA should be supported by all Nigerians in spite of short term demerits that may arise from its implementation. The key benefits of the TSA will be derived from its ability to significantly improve revenues accruing to the federation account, and also enhancing effective financial management through proper scrutiny and approval of public expenditures. It is however important that initiatives be 
developed to address the challenges TSA might create for smooth running of universities and research institutes in the country. It is inconceivable that the country will attain national educational and technological development without properly attention to research development. Hence, while taking steps to boost effective financial management in the country, the capacity for sustainable research development must not be compromised in the country.

\section{Limitations of Study}

The inferences made in this study may be affected by three limitation of study. The sample size was purposive; the disadvantage of this method is that, some eligible respondence may have been excluded from the study. Inferential statistical methods, such as regression analysis and other parametric methods have not being used to established course-effect relationship in the study. Most part of the analysis carried out have being descriptive, the implication of this descriptive method is that no hypotheses have being tested in the study.

However, the descriptive analysis carried out summarises general understanding and opinion of TSA implementation in the country. The effect of TSA implementation as measured in the study were not linked to aggregate statistics on sectors of the economy impacted by the TSA implementation. The opinion and perception of respondence as reported in the study may not align with aggregate statistics on the effect of TSA implementation in the country. This implies that the study was based on self report by the respondence. However, adequate steps were taking during the field work to ensure that responses are precise and trustworthy

\section{Conclusion}

This study has examined opinion and perception of TSA implementation in Nigeria. The study provided additional evidence that TSA implementation is beneficial to public sector accounting in the country. It is however important to take steps to address the short-term challenges that may arise from its implementation.

\section{References:}

1. Adeolu, I.A (2015).Understanding the treasury single account systemthings you should know:

2. Stalwart report August 1 2015, News press

3. Augustine, C. (2016). ASUU berates FGN over paucity of funds in varsities: Punch Newspaper August 27, 2016. North East Coordinator of ASUU

4. Charls, A. (2016). ASUU Rejects TSA: Says it Cripples Varsity: Punch News Paper March 312016 
5. Clement, U. A.(2015). The Nigerian Politics of Understanding the Treasury Single Account (TSA) International Journal of Advanced Research in Engineering \& Management (IJAREM) 1, 23 -29

6. Eme, O. I, \& Chukwurah, D. C. (2015). An Analysis of Pros and Cons Treasury Single Account Policy in Nigeria: Arabian Journal of Business and Management Review (OMAN Chapter) 5, 20-39

7. Isa, A. A (2016). The Treasury Single Account as an Instruments of financial prudence and Management: Prospects and Problems. Research Journal of Finance and Accounting, 7, 66-71

8. Kanu, C. (2016). Impact of Treasury Single Account on the Liquidity. ABC Journal of Advanced Research, 5, 43-51

9. Kolapo, O. (2015). Opinion, Buhari and the Treasury Single Account: Naija the Internet Newspaper, Sept 24, 2015

10. Kanu\&Oyims, (2015). Financial Exclusion of Small and Medium Enterprise and Poverty Alleviation: Nigeria Experience. Archives' of Business Research, 3, 63-77.

11. Lienert, I. (2009). Modernizing Cash Management: Technical Notes and Manuals. Washington, DC, USA: Fiscal Affairs Department, International Monetary Fund

12. Mohammed, S. (2016). The victims, Gainers of treasury single account. Daily trust newspaper Monday January 2016

13. Mustapha, S. (2016). ASUU Want FG to Remove University System from TSA. Daily trust Newspaper, October 24, 2016

14. Ngozi, O.I (2015). Vanguard edition 2015 pp17

15. Oguntodu, J. A., Ala;ade, Y.S.A.,Adekunle \& Adegbei, (2016). Measuring Single Account and Nigeria Economy Between 1999 and 2015 An Assessment: journal of account and financial management. 2, 62-74

16. Onyekpere, N. N. (2015). Public Policy: Effects of Treasury Single Account on Nigerian banks. Vanguard Newspaper Editorial, August 14 p. 15

17. Obi, p. (2016). TSA implementation crippling university system; ASSU cries out, these day Newspaper march, 31, 2016

18. Ocheni, S. (2016). Treasury single account: A catalyst for public financial management in Nigeria

19. Olanipekun, W. D., Brimah, A.N. \& Olowoleni, F. M.(2015). Treasury Single Account (TSA): A Strategy For Combating Corruption and Achieving Sustainable Development. Journal of Sustainable Development in Africa. 17, 139-148

20. Philip, S. (2015). Treasury Single Account; Bank Deposit loss may hit 2trn, news telegraph editorial August 17, pp18 
21. Udo, E. J., Esara, I. E. (2016). Adoption of Treasury Single Account (TSA) by State Governments of Nigeria: Benefits, Challenges and Prospects. Journal of Finance and Accounting, 4, 126-130, doi: 10.11648/j.jfa.20160403

22. Utsu, E. A., Mohammed. M. B., \&Obukeni, C. O.(2016). An Assessment of the Treasury Single Account Policy on Nigeria Economy Social Sciences Journal of Policy Review and Development Strategies Hard Print: 2488-9636 Online: 2488-9628 Vol. 2, No. 1 April, $\backslash 2016$ International Standard Research Publishing pp. 74-82

23. Taiwo, O. (2015). Treasury single account implications: West Africa Tax Leader at PWC, President at Impact Africa foundation, council member ACCA. Published October 10, 2015

24. Yusuf, O. M., Abdullahi, G. B., Emmanuel, I. U. \& Emmanuel, O. C.(2015). The Impacts of Treasury Single Account (TSA) On Ministries, Departments and Agencies (MDA's).

Accounting Information and Accountability: A Conceptual Review Proceedings of The Academic Conference of Sub-Sahara African Academic Research Publications on New Direction and Uncommon Changes Vol. 2 No. 4. 5th - 6th November, 2015- Mal. Audu Auditorium Hall, Federal Polytechnic, Bauchi, Bauchi State 